XXXVI. On a New Genus of Balanophoreæ from New Zealand, and Two New Species of Balanophora. By J. D. HOOKER, M.D., F.R.S. \& L.S. \&c.

Read June 16th, 1859.

SINCE laying before the Linnean Society my observations on the structure and affinities of Balanophorea* ${ }^{*}$ I have received two additional species of Balanophora, and a remarkable new genus of the Order, which I shall now proceed to describe under the name of Dactylanthus.

\title{
Dactrlanthus, n. g.
}

Dioicum. Rhizoma tuberosum, lobatum. Pedunculi plurimi, squamati, apice spadices plurimos gerentes. Flores in spadices dense conferti, inferiores dissiti. FL. MAsc. Stamen solitarium sessile, filamento brevissimo, anthera 2-loculari. FL. FGM. Perianthium ovario globoso subsessili adnatum, lobis 2-3 subulatis, stylo filiformi, stigmate simplici.

\section{Dactylanthus Taylori, H.f. (Tab. LXXV. A.)}

Hab. Nova Zelandia ad radices Fagi et Pittospori montibus prope Wanganui, alt. 4000 ped. (Rev. R. Taylor, M.A.). Nom. vern. Pua reinga (Flos Hades).

Rhizoma magnitudine pugilli et ultra, tuberculatum, superficie celluloso, pustulis papillisve nullis, intus sicco rubrum. Pedunculi numerosi, 4-6 unc. alti, sicco fragiles, rugulosi, opaci, ferruginei, intus rufescentes, squamis imbricatis laxe tecti, apice in receptaculum floriferum dilatati. Squame oblongæ, obtusæ, lata basi sessiles, inferiores dissitæ, $\frac{1}{4}$ unc. longæ, brunneæ, superiores sensim majores, supremæ inflorescentiam involucrantes, 1-2 unc. longæ, lineari-oblongæ, membranaceæ, albæ medio sordide brunneæ v. rubræ. Spadices (v. pedicelli floriferi) 10-30, conferti, erecti, 1-2 unc. longi, cylindracei $\mathrm{v}$. fusiformes, crassitie pennæ corvinæ, stipitati, basi nudi v. floribus deformatis bracteolati. Flores dense conferti. MAsc. Stamen solitarium nudum, sessile, filamento brevissimo crasso; anthera adnata, 2-locularis, transverse oblonga, rimis subverticalibus dehiscens, loculis crassiusculis, inferiores in spica imperfectæ dissitæ stipitatæ. Pollen pallidum, globosum. FL. Form. sicco nigri, sub $\frac{1}{10}$ unc. longi. Ovarium stipitatum, subglobosum. Perianthium supra ovarium paulo angustatum, dein bi-, rarius 3-partitum, a dorso compressum, cum stylo connatum; segmentis respectu. axeos lateralibus, subulatis, inæqualibus. Stylus cylindricus, teres, superne paulo incrassatus, apice obtusus._- Planta viva odorem subgratum Melonis, sed demum ingratum humi spirat."-Taylor.

For a specimen of this singular plant I am indebted to my friend the Rev. R. Taylor, of New Zealand, who brought a fragment of it to England in 1856, and on my pointing out its probable interest, promised to procure more on his return to New Zealand. This he did; and early in the present year I had the pleasure of receiving from him a dried specimen of the female plant, a perfect male inflorescence in a letter, and a pen and ink sketch of the peduncle and flowers, with notes on the same. Owing to the great contraction of the cellular tissue, and blackening and fragility of the only entire specimen, which was unfortunately loosely packed in a box and much damaged, I have had considerable difficulty in so restoring the parts as to enable Mr. Fitch to complete the accompanying Plate, and myself to make the necessary analyses. 
The most remarkable character of Dactylanthus is its inflorescence, which, instead of presenting the solitary capitulum or spadix of most of its allies, or the branched character of Sarcophyte, consists of numerous erect spadices, densely covered with flowers. Of these the males consist of a solitary stamen, not articulate with the spadix, and without any trace of perianth, and hence present by far the most reduced form of male flower in the Order. The female spadices present a crinite appearance from the long flexuose styles of the flowers. The ovary appears to be compressed, furnished with a short thick stipes, and its upper part is contracted into a short thick neck, apparently consisting of the tube of the perianth connate with the base of the style: this contracted part varies much in width and breadth, and sometimes appears as if reduced to the adnate bases of the subulate lobes of the perianth.

I have not been able to ascertain the nature either of the contents of the ovary, which is extremely minute, and crumbles into black powder on being touched, or of the tissues of the rhizome and peduncle, which do not seem to differ materially from those of other Balanophorea.

The position of Dactylanthus is amongst my first group of Balanophorea, the Monostyli; but in many respects it partakes of the structure of various genera of Distyli, and is not very nearly related to any described genus. In habit it presents the rhizome of Balanophora. In the male flowers reduced to a solitary stamen, it agrees with Lophophytum and Thonningia, and in the subulate perianth-lobes of the female flower with Cynomorium. Upon the whole it may perhaps rank nearest to Thonningia, with which it agrees in habit, in some points of structure of the female flower, especially in the tube of the perianth being connate with the style above the ovary, in the absence of imperfect flowers amongst the females, of bracts, and of a perianth to the male flower.

The natives of New Zealand call this plant " Flower of Hades," because it grows almost buried in the soil; they further consider it allied to Freycinetia, which it strikingly resembles in the inflorescence.

Mr. Taylor informs me that he has heard vaguely of the existence of another species with blue flowers in the forests of Mount Egmont.

2. Balanophora Harlandi, H. f. Dioica, rhizomate parvo lobato epustulato, pedunculo ima basi bracteis subfoliaceis involucrato, capitulo globoso, floribus fœmineis capitulo sessilibus. (TAB. LXXV. B.)

Hab. Sylvis insulæ Hongkong (Harland); in convalle Mont. Gough (C. Wilford, Dec. 1858).

Species pusilla, 1-3 pollicaris, ab omnibus differt pedunculo basi tantum squamato; et preterea a B. divica, eapitulo globoso, et rhizomate epustulato; a B. fungosa capitulo unisexuali globoso, floribus fœmineis capitulo (non pedicello bracteolæ) sessilibus.

3. Batanophora Lowir, H. f. Dioica, rhizomate parvo papilloso et pustulato, pedunculo brevi, squamis inferioribus parvis, superioribus magnis numerosis imbricatis concavis capitulum velantibus, capitulo fl. $\delta$ oblongo, receptaculo columnari, perianthio 4-fido, lobis lateralibus angustioribus. (TAB. LXXV.C.)

Hab. Sylvis umbrosis montis Kina Balou, insulæ Borneo (H. Low). 


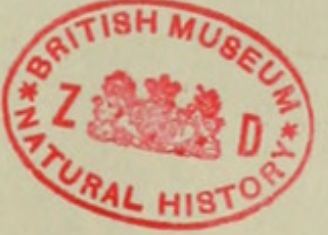




\section{$2 \mathrm{BHL}$ Biodiversity Heritage Library}

Hooker, Joseph Dalton. 1859. "On a New Genus of Balanophoreæ from New Zealand, and Two New Species of Balanophora." Transactions of the Linnean Society of London 22, 425-427. https://doi.org/10.1111/j.1096-3642.1856.tb00114.x.

View This Item Online: https://www.biodiversitylibrary.org/item/46591

DOI: https://doi.org/10.1111/j.1096-3642.1856.tb00114.x

Permalink: https://www.biodiversitylibrary.org/partpdf/14297

\section{Holding Institution}

Natural History Museum Library, London

\section{Sponsored by}

Natural History Museum Library, London

\section{Copyright \& Reuse}

Copyright Status: Public domain. The BHL considers that this work is no longer under copyright protection.

This document was created from content at the Biodiversity Heritage Library, the world's largest open access digital library for biodiversity literature and archives. Visit BHL at https://www.biodiversitylibrary.org. 